Monika Kłos, Małgorzata Burzyńska

Wyższa Szkoła Biznesu w Pile

\title{
Model kształcenia przez całe życie w budowaniu potencjału rozwojowego uczelni
}

\author{
The new model of lifelong learning in creating university's \\ developmental potential
}

Streszczenie. Celem artykułu jest podkreślenie roli szkół wyższych w planowaniu i organizowaniu kształcenia przez całe życie, zwłaszcza w perspektywie koncepcji dzielenia się wiedzą, która była testowana podczas realizacji projektu innowacyjnego współfinansowanego ze środków Unii Europejskiej w ramach Europejskiego Funduszu Społecznego. Na wstępie autorki opisują założenia projektu „PI: Nowy model kształcenia przez całe życie w budowaniu potencjału rozwojowego uczelni”, realizowanego przez Wyższą Szkołę Biznesu w Pile. Następnie omawiają przebieg konferencji naukowych dotyczących innowacyjnego modelu kształcenia przez całe życie zorganizowanych w czterech różnych uczelniach.

Słowa kluczowe: kształcenie przez całe życie, dzielenie się wiedzą, coaching, mentoring.

\begin{abstract}
The aim of the article is to outline the role of the university in planning and organizing lifelong learning, taking into consideration the perspective of the possibility of knowledge sharing, applied during the implementation of a project co-financed by the European Union within the European Social Fund. First, the authors draw the basic concepts of the project "PI: The new model of lifelong learning in creating university's developmental potential," implemented at the Higher School of Business in Pila. Second, they describe scientific conferences devoted to the innovative model of lifelong learning organized by four different institutions of higher education.
\end{abstract}

Keywords: lifelong learning, knowledge sharing, elements of coaching and mentoring.

Realizacja projektu innowacyjnego „Nowy model kształcenia przez całe życie w budowaniu potencjału rozwojowego uczelni" przebiegała w okresie: 
styczeń 2012 r.-grudzień 2014 r. W tym czasie kluczowe działania skupiono wokół sześciu zadań, które zostaną w sprawozdaniu kolejno omówione:

1. Diagnoza i analiza problemu,

2. Opracowanie wstępnej wersji produktu finalnego oraz strategii wdrażania projektu,

3. Testowanie opracowanego produktu,

4. Analiza rzeczywistych efektów testowanego produktu,

5. Opracowanie ostatecznej wersji produktu finalnego,

6. Upowszechnianie i włączanie produktu do głównego nurtu polityki.

Głównym celem podjętych działań było opracowanie, przetestowanie i promocja nowego modelu kształcenia przez całe życie (zwanego dalej Modelem). Jego podstawowe założenie odwołuje się do koncepcji dzielenia się wiedzą i wykorzystania elementów coachingu i mentoringu w kształceniu ustawicznym. Organizacja kształcenia każdorazowo realizowana jest w ramach dwóch ścieżek: rozwoju potencjału osobistego i kierunkowej. Podstawową formą pracy podczas zajęć jest praca w parach, w której jedna osoba pozostaje w „tradycyjnym wieku studenckim” (18-24 lata), a druga go przekroczyła (25+). Na Model składają się 32 elementy, które umożliwiają realizację czterech różnych bloków szkoleniowych. Są to: 4 programy zajęć, 20 materiałów do realizacji zajęć, 4 części programu warsztatów metodycznych, nawigator LLL (aplikacja informatyczna do pomiaru efektów kształcenia) z materiałami informacyjno-instruktażowymi dla użytkowników, narzędzie do diagnozowania luk kompetencyjnych (składnik Nawigatora LLL), podręcznik przygotowywania programów zajęć w oparciu o koncepcję dzielenia się wiedzą; instrukcja stosowania produktu finalnego, „Katalog dobrych praktyk w zakresie włączania kształcenia przez całe życie realizowanego w oparciu o koncepcję dzielenia się wiedzą do oferty dydaktycznej uczelni".

Model może być w całości lub w części zaimplementowany do oferty edukacyjnej każdej uczelni, ponieważ umożliwia wykorzystanie jej potencjału w zakresie kształcenia ustawicznego. Projekt był współfinansowany z środków Unii Europejskiej w ramach Europejskiego Funduszu Społecznego - Priorytet IV - Szkolnictwo wyższe i nauka.

W ramach pierwszej fazy realizacji projektu (zadanie 1) przeprowadzono badania $\mathrm{w}$ postaci zogniskowanych wywiadów grupowych wśród ekspertów w zakresie kształcenia ustawicznego oraz przedstawicieli szkół wyższych (tematyka sesji: „Uwarunkowania integracji funkcjonujących modeli kształcenia ustawicznego w warunkach polskich”, „Nowoczesne metody i formy dydaktyczne w kształceniu przez całe życie. Uwarunkowania 
i możliwości implementacji w warunkach polskich”, „Kształcenie przez całe życie jako instrument poprawy konkurencyjności uczelni w sytuacji zmiany"), które pogłębiono przez analizę desk-research. Na ich podstawie określono problemy związane $z$ niskim poziomem dostosowania oferty uczelni do zmian społeczno-ekonomicznych zachodzących w kraju oraz obecną sytuacją na rynku. W perspektywie wskazanych przemian w raporcie opracowanym na podstawie badań podkreślono potrzebę realizacji kształcenia ustawicznego również przez uczelnie, a tym samym uzyskano rekomendację dla projektu.

Kolejny etap realizacji projektu przebiegał dwufazowo - z jednej strony przeprowadzono seminaria na temat założeń produktu finalnego oraz debatę dotyczącą wstępnej wersji produktu finalnego $\mathrm{z}$ udziałem zespołu projektowego i przedstawicieli grup docelowych, $\mathrm{z}$ drugiej strony opracowano materiały do realizacji zajęć oraz aplikację informatyczną do diagnozowania luk kompetencyjnych (łącznie 33 elementy). Efektem tego zadania było opracowanie wstępnej wersji produktu finalnego oraz strategii wdrażania projektu innowacyjnego testującego, która została poddana ocenie i uzyskała ostateczną akceptację Narodowego Centrum Badań i Rozwoju będącego Instytucją Pośredniczącą dla IV Priorytetu POKL we wrześniu 2013 roku.

Testowanie produktu finalnego, czyli sprawdzenie jego skuteczności w warunkach rzeczywistych stanowiło 3. zadanie projektu. Do realizacji zajęć, opracowanych zgodnie z założeniami Modelu, w ramach czterech bloków szkoleniowych, przystąpiły następujące uczelnie: Państwowa Wyższa Szkoła Zawodowa w Wałczu, Wyższa Szkoła Nauk Humanistycznych i Dziennikarstwa w Poznaniu, Wyższa Szkoła Gospodarki w Bydgoszczy oraz Wyższa Szkoła Biznesu w Pile. W tej fazie brało udział: 16 użytkowników (8 osób z kadry kierowniczej i 8 osób z kadry dydaktycznej - po 4 przedstawicieli z każdej uczelni) oraz 80 odbiorców (po 20 osób, które uczestniczyły w zajęciach prowadzonych w każdej z 4 uczelni, w tym 10 osób było w wieku 18-24 lata i 10 osób, które przekroczyły „tradycyjny” wiek studencki - 25-64 lata). Etap przygotowawczy w tym zakresie stanowiły dwa zadania - opracowanie zaplecza badawczego oraz przeprowadzenie warsztatów metodycznych dla prowadzących zajęcia (kadry dydaktycznej uczelni) służących omówieniu Modelu i opracowaniu zasad jego testowania.

Ocenie i analizie testowanego Modelu służyło następne zadanie, w ramach którego dokonano ewaluacji zewnętrznej produktu finalnego. Spotkanie warsztatowe ewaluatora z zespołem projektowym doprowadziło do określenia wytycznych i kierunków zmian w produkcie finalnym, które zostały zaprezentowane w Raporcie nr 2 z ewaluacji okresowej wstępnej wersji 
produktu finalnego pt. „Model kształcenia przez całe życie oparty na koncepcji dzielenia się wiedzą i adaptacji coachingu i mentoringu na gruncie edukacji ustawicznej" (Prepost Consulting Alicja Zajączkowska).

Wewnętrznej i zewnętrznej ocenie jakości Modelu służyły także działania podjęte zgodnie z zadaniem 5 , którego celem było opracowanie ostatecznej wersji produktu finalnego. W związku z tym przygotowano produkt finalny i przekazano go do recenzji ekspertom zewnętrznym, dokonano zmian w opisie Modelu oraz jego poszczególnych składnikach i ostatecznie przekazano produkt do walidacji. Podczas posiedzenia Krajowej sieci Tematycznej w obszarze Edukacja i Szkolnictwo Wyższe w Warszawie (wrzesień 2014 r.) członkowie zespołu projektowego - dr Monika Kłos i dr Małgorzata Burzyńska omówiły Model, w tym koncepcję dzielenia się wiedzą, jego składniki oraz wnioski i rekomendacje z okresu testowania. Pozytywny przebieg głosowania zadecydował o pozytywnej walidacji produktu finalnego, co pozwoliło na realizację kolejnego zadania - upowszechniania i włączania produktu do głównego nurtu polityki.

Należy podkreślić, że zadanie 6 związane $\mathrm{z}$ upowszechnianiem było prowadzone przez cały okres realizacji projektu, ale najbardziej intensywne działania w tym zakresie podjęto po pozytywnej walidacji produktu finalnego. W sprawozdaniu zostaną omówione następujące inicjatywy:

- nagranie podcastów i filmu instruktażowego - będących formą przewodnika dla kadry kierowniczej i dydaktycznej uczelni zainteresowanych wdrożeniem produktu,

- działalność ekspertów projektu,

- przygotowanie publikacji „Perspektywy kształcenia ustawicznego w uczelni. Dobre praktyki projektu Nowy model kształcenia przez całe życie w budowaniu potencjału rozwojowego uczelni”,

- cykl konferencji upowszechniających połączonych z warsztatami dla kadry dydaktycznej/kierowniczej uczelni.

Jednym z głównych działań w zakresie upowszechniania było nagranie filmu instruktażowego oraz podcastów prezentujących Model i stanowiących wsparcie w jego wdrożeniu dla przedstawicieli kadry dydaktycznej/ kierowniczej uczelni. Ich zaletą jest przede wszystkim możliwość szerokiej dystrybucji i odtwarzania w dowolnym miejscu i czasie, również po zakończeniu projektu. Zarówno podcasty, jak i film instruktażowy stanowią rodzaj przewodnika dla kadry kierowniczej/dydaktycznej uczelni wyższych wprowadzających Model. Treści materiałów filmowych dotyczą składników produktu finalnego i przykładowego sposobu ich wykorzystania (film) oraz prowadzenia zajęć ze ścieżki ścieżkę rozwoju osobistego, praktycznych 
aspektów stosowania coachingu i mentoringu, możliwości przygotowania bloku szkoleniowego, a także zawierają rekomendacje z okresu jego testowania (4 części podcastów).

W celu możliwie szerokiego upowszechnienia i włączenia produktu do głównego nurtu polityki, prowadzonego w formie bezpośredniej, powołano zespół ekspertów. Wszystkie podejmowane przez nich działania sprzyjały zapewnieniu trwałości efektów projektu i obejmowały: prowadzenie spotkań lobbingowych, szkolenia z metodyki Modelu oraz wsparcie coachingowe dla przedstawicieli kadry kierowniczej/dydaktycznej uczelni, którzy zadeklarowali możliwość włączenia Modelu do oferty edukacyjnej. W efekcie działań prowadzonych przez ekspertów, 14 uczelni z terenu całego kraju złożyło deklarację o wdrożeniu produktu finalnego lub jego składników do własnych inicjatyw w zakresie kształcenia ustawicznego.

Równolegle prowadzonym przedsięwzięciem było opracowanie publikacji „Perspektywy kształcenia ustawicznego w uczelni. Dobre praktyki projektu Nowy model kształcenia przez całe życie w budowaniu potencjału rozwojowego uczelni” pod redakcją dr Moniki Kłos i dr Małgorzaty Burzyńskiej. Stanowi ona omówienie koncepcji dzielenia się wiedzą ze wskazaniem możliwości jej zastosowania, ale poruszono w niej także zagadnienia dotyczące roli szkół wyższych w planowaniu i organizowaniu kształcenia ustawicznego (m.in. wykorzystanie coachingu i mentoringu w pracy nauczyciela akademickiego, diagnozowanie luk kompetencyjnych, praca w parach, łączenie ścieżki rozwoju osobistego ze ścieżką kierunkową w programie jednego szkolenia). Dodatkowo należy wspomnieć, że w czasopiśmie „Perspektywy” oraz „Edukacja Ustawiczna Dorosłych” zamieszczono inserty prezentujące Model.

Upowszechnianie było prowadzone również w trakcie czterech konferencji, którym towarzyszyły warsztaty dla kadry kierowniczej i dydaktycznej uczelni, podczas których zaprezentowano możliwości zastosowania Modelu i jego włączenia do oferty edukacyjnej uczelni oraz propozycje wykorzystania coachingu i mentoringu w edukacji dorosłych. Uczestnicy warsztatów otrzymali opracowania umożliwiające wdrożenie Modelu, w tym: materiały szkoleniowe, programy zajęć, opracowania metodyczne dla osób przygotowujących trenerów (lub dla nich samych) do stosowania Modelu (program warsztatów metodycznych) oraz dostęp do aplikacji informatycznej umożliwiającej dzielenie się wiedzą oraz diagnozę luk kompetencyjnych uczestników szkolenia. Warsztaty umożliwiły także oprócz zapoznania się z Modelem wymianę refleksji dotyczących roli uczelni w prowadzeniu kształcenia ustawicznego. 


\section{6 | Monika Kłos, Małgorzata Burzyńska}

Doświadczenia zdobyte w trakcie realizacji projektu oraz wyniki ewaluacji zewnętrznej pozwalają wskazać, że koncepcja dzielenia się wiedzą z elementami coachingu i mentoringu sprawdza się w praktyce, a jej zastosowanie, zarówno w opinii uczestników szkolenia, jak i przedstawicieli uczelni, jest motywujące do rozwoju. Wypracowany przez Wyższą Szkołę Biznesu w Pile innowacyjny Model może być łatwo wdrożony w szkołach wyższych, a tym samym jego założenia mogą być wykorzystane w długofalowej strategii rozwoju kształcenia ustawicznego. 